\author{
Justisia Ekonomika \\ Jurnal Magister Hukum Ekonomi Syariah \\ Vol 5, No 2 tahun 2021 hal 271-284 \\ EISSN: 2614-865X PISSN: 2598-5043 \\ Website: http://journal.um-surabaya.ac.id/index.php/JE/index
}

\title{
KEPASTIAN HUKUM STATUS KEPEMILIKAN TANAH RUMAH SUSUN PERSPEKTIF HUKUM EKONOMI SYARIAH
}

\author{
Dzulkarnain Alghafuru Syahputra \\ Universitas Brawijaya Malang \\ e-mail: ghofuralghafuru@yahoo.co.id
}

\begin{abstract}
The developer of the apartment is allowed to sell the apartment unit that has not been completed after fulfilling the requirements and obligations as regulated in Article 43 paragraph (2) of the Flats Law. This study aims to analyze and find the accuracy of using Article 378 of the Criminal Code to adjudicate violations of Article 43 paragraph (2) of the Flats Law related to the certainty of land ownership status as the basis for making PPJB and criminal responsibility for notaries against the occurrence of criminal acts in the deed he made related to with the principle of prudence of a notary in carrying out his office. The research method used in this study is normative juridical law research, the approach method used is the statutory regulation approach and the conceptual approach as well as the case approach. From the results of the research and discussion, it can be concluded first: the use of Article 378 of the Criminal Code which is applied to violations of Article 43 paragraph (2) of the Flats Law is inappropriate. The appropriate article for the violation is Article 110 of the Flats Law. Second: For criminal acts that are contained in a notary deed, it can cause the notary to be held criminally responsible for participating in helping the occurrence of a crime. In Sharia Economic Law, land ownership in flats includes haq al-jiwar which is included in the realm of al-irtifaq rights, where every occupant of the flat is entitled to the land where the house they live in is built.
\end{abstract}

Keywords: flats, violation, criminal, Haq al-Irtifaq.

\section{A. PENDAHULUAN}

Kebutuhan tempat tinggal bagi masyarakat tidak sebanding dengan ketersediaan tanah yang ada, terutama di daerah perkotaan yang padat akan permukiman. Hal ini berakibat pada harga tanah serta rumah yang tinggi dikarenakan kota besar merupakan pusat perekonomian serta perindustrian, dimana gedung perkantoran atau tempat kerja berada relatif jauh dari tempat tinggal. Untuk itu masyarakat membutuhkan tempat tinggal yang lebih dekat dengan gedung perkantoran atau tempat kerja, namun dengan harga yang ekonomis. Sebagai alternatif untuk menjawab keterbatasan tanah dan tempat tinggal yang lebih ekonomis di kotakota besar, sudah saatnya pemenuhan tempat tinggal atau rumah sebagai 
hunian di perkotaan dilakukan dengan pembangunan rumah secara vertikal dengan rumah susun. ${ }^{1}$

Seiring dengan perkembangan perekonomian serta meningkatnya kebutuhan akan perumahan di kotakota besar melalui rumah susun, hal ini harus didukung dengan perangkat hukum yang melandasinya, sehingga hubungan hukum antara pelaku pembangunan rumah susun dengan masyarakat yang memerlukan satuan rumah susun menjadi jelas dan berkepastian hukum. Negara merasa perlu menggariskan kebijakan dan menetapkan ketentuan-ketentuan untuk keperluan penyelenggaraan rumah susun, dan juga merasa perlu untuk menetapkan hal-hal yang harus dipatuhi dan larangan-larangan yang tidak boleh dilakukan oleh pelaku pembangunan rumah susun. Penyelenggaraan rumah susun di atur dalam Undang-Undang Nomor 20 Tahun 2011 tentang Rumah Susun (selanjutnya disebut UURS), antara lain pengaturan Pasal 43 ayat (2) yang mengatur persyaratan dan kewajiban bagi Pelaku Pembangunan atau Pengembang Rumah Susun yang melakukan penjualan satuan rumah susun (sarusun) yang belum selesai dibangun dengan sistem Perjanjian Pendahuluan Jual Beli (PPJB).

Walaupun UURS telah memberikan pengaturan yang tegas dan jelas dalam rangka penyelenggaraan rumah susun, akan tetapi kepatuhan masyarakat yang menjadi pelaku pembangunan rumah susun dan juga masyarakat yang menjadi calon pembeli rumah susun masih tergolong rendah. Sehingga pembentuk UURS merasa perlu

${ }^{1}$ Siswono Judohusodo, Rumah Untuk Seluruh Rakyat, (Jakarta: Inkoppol Unit Percetakan Bharakerta, 1991), hlm. 27. melibatkan Notaris dalam penyelenggaraan rumah susun. Hal tersebut tercermin pada ketentuan Pasal 43 ayat (1) UURS yang melibatkan notaris dalam pembuatan PPJB antara developer dengan pembeli rumah susun.

Penulis menemukan isu hukum bahwa aparat penegak hukum mulai dari kepolisian, kejaksaan hingga hakim pengadilan pada putusan pengadilan di atas, baik penuntutan dan putusan yang diberikan tidak menggunakan ketentuan Pasal 98 UURS sebagai delik pidana dan Pasal 110 UURS sebagai ancaman pidananya, akan tetapi menggunakan ketentuan Pasal 378 KUHP. Tindak pidana dalam penyelenggaraan rumah susun oleh pelaku pembangunan berawal dari tidak dibuatnya PPJB di hadapan Notaris.

Tujuan yang hendak dicapai melalui penelitian ini adalah untuk menganalisis dan menemukan ketepatan penggunaan Pasal 378 KUHP untuk mengadili pelanggaran Pasal 43 ayat (2) Undang-Undang Nomor 20 Tahun 2011 tentang Rumah Susun terkait kepastian status kepemilikan tanah sebagai dasar pembuatan PPJB dan tanggung jawab pidana bagi notaris terhadap terjadinya tindak pidana di dalam akta yang dibuatnya dikaitkan dengan prinsip kehati-hatian notaris dalam menjalankan jabatannya.

\section{B. METODE PENELITIAN}

Jenis penelitian ini adalah penelitian kualitatif. Metode penelitian yang digunakan dalam penelitian ini adalah penelitian hukum yuridis normatif, ${ }^{2}$ yang juga disebut penelitian hukum doktrinal.

2 Peter Mahmud Marzuki, Penelitian Hukum, Cetakan 14, (Jakarta: Kencana Prenada Media Group, 2019), h. 29-35. 
Pendekatan yang digunakan adalah pendekatan peraturan perundangundangan (statute approach) yang dilakukan dengan menelaah peraturan perundang-undangan dan regulasi yang bersangkut paut dengan isu hukum yang sedang ditangani, dan pendekatan konseptual (conseptual approach) yang beranjak dari pandangan-pandangan para ahli dan doktrin-doktrin yang berkembang di dalam ilmu hukum, guna menemukan ide-ide yang

\section{HASIL dan PEMBAHASAN Ruang Lingkup Pembangunan Rumah Susun}

\section{Tanah Bersama}

\section{Perolehan Hak Atas}

Menurut Pasal 17 UURS, pembangunan rumah susun dapat dilakukan di atas tanah Hak Milik (HM)

1) Hak Guna Bangunan (HGB) atau Hak Pakai (HP) di atas tanah negara

2) Hak Guna bangunan (HGB) atau Hak Pakai (HP) di atas tanah Hak Pengelolaan (HPL)

Pengaturan Pasal 17 UU Rumah Susun tersebut dilandasi oleh konsep hak-hak atas tanah yang terdapat dalam Hukum Tanah Nasional yang membagi hak-hak atas tanah dalam dua bentuk yaitu :

1) hak-hak atas tanah yang bersifat primer yaitu hak yang langsung diberikan oleh negara kepada pemegang haknya seperti Hak Milik (HM), Hak Guna Usaha (HGU), Hak Guna Bangunan (HGB), Hak Pakai (HP).

2) hak-hak atas tanah yang bersifat sekunder yaitu hak yang timbul atau dibebankan diatas hak atas tanah yang sudah ada. Hak ini bisa timbul karena perjanjian antara pemilik tanah sebagai pemegang hak melahirkan pengertian, konsep dan asas hukum yang relevan, sebagai pijakan dalam membangun suatu argumentasi hukum sebagai preskripsi dalam memecahkan isu hukum yang dihadapi, serta pendekatan kasus (case approach) yang dilakukan dengan menelaah kasus-kasus yang terkait dengan isu hukum serta memahami ratio decidendi atau alasan hakim dalam memberikan putusan.

primer dan calon pemegang Hak Sekunder. Hak sekunder ini ditumpangkan di atas hak lain yang memiliki derajat yang lebih tinggi misalnya HGB/HGU/Hak Pakai di atas tanah Hak Milik atau Hak Pengelolaan.

Persiapan untuk memperoleh hak atas tanah bersama yang akan dijadikan proyek rumah susun memiliki tahapan perijinan sebagai berikut:

\section{a. Advice Planning}

Advice Planning adalah surat rekomendasi teknis yang dikeluarkan oleh Badan Perencanaan Pembangunan Daerah (Bappeda), yang memuat memuat keterangan zonasi dan batasan intensitas bangunan yang sesuai dengan arahan tata ruang daerah.

b. Izin Lokasi Dari Online Single Submision (OSS)

Lahan yang akan dijadikan proyek pembangunan rumah susun yang telah sesuai dengan Rencara Tata Ruang dan Wilayah (RTRW), maka pelaku usaha dapat mengajukan Izin Lokasi dalam rangka pemenuhan komitmen melalui OSS.

Izin lokasi adalah izin yang diberikan kepada pelaku usaha yang akan memperoleh tanah untuk 
kebutuhan usaha. Izin Lokasi tersebut juga bisa melakukan perolehan/pemindahan hak untuk penggunaan tanah sebagai kebutuhan usaha dan atau melakukan kegiataan lainnnya. ${ }^{3}$

c. Pertimbangan Teknis

Pertanahan

Izin lokasi sebagaimana dimaksud di atas, telah diatur dalam Peraturan Menteri Agraria Dan Tata Ruang/Kepala Badan Pertanahan Nasional Republik Indonesia Nomor 17 Tahun 2019 (selanjutnya disingkat Permen ATR/KBPN No. 17/2019).

Izin lokasi yang diterbitkan melalui sistem OSS di atas, masih diperlukan persetujuan dari kepala daerah yaitu Bupati/Walikota, khusus untuk DKI dari Gubernur. Oleh karenanya, persyaratan untuk memperoleh persetujuan dari kepala daerah dimaksud, harus melampirkan pertimbangan teknis pertanahan yang diterbitkan Kantor Pertanahan.

d. Persetujuan Izin Lokasi

\section{Perizinan Pembangunan} Rumah Susun

Setelah pengembang memperoleh kepastian ruang dan kepastian hak atas tanah, selanjutnya masih diperlukan izin-izin lain sebagai persyaratan pembangunan rumah susun, yaitu:

a. Persetujuan Bangunan Gedung

Istilah Persetujuan

Bangunan Gedung (PBG) merupakan istilah pengganti dari Izin Mendirikan Bangunan

${ }^{3}$ Pasal 1 ayat (1) Peraturan Menteri Agraria Dan Tata Ruang/Kepala Badan Pertanahan Nasional Republik Indonesia Nomor 17 Tahun 2019 Tentang Izin Lokasi.
(IMB). Istilah PBG mengacu pada perubahan UURS yang diubah dengan Pasal 56 UndangUndang Nomor 11 Tahun 2020 tentang Cipta Kerja (selanjutnya disebut UUCK).

\section{Penjualan Satuan Rumah Susun}

a. Penjualan Langsung

Pengembang yang membangun dan mengusahakan rumah susun merupakan pihak yang dapat merupakan pemilik tanah dan atau bukan pemilik tanah. Selanjutnya hak pengembang atas rumah susun tersebut dibagi-bagi lagi menjadi:

1) tanah bersama adalah sebidang tanah hak atau tanah sewa untuk bangunan yang digunakan atas dasar hak bersama secara tidak terpisah yang di atasnya berdiri rumah susun dan ditetapkan batasnya dalam persyaratan izin mendirikan bangunan.

2) benda bersama adalah benda yang bukan merupakan bagian rumah susun melainkan bagian yang dimiliki bersama secara tidak terpisah untuk pemakaian bersama.

3) bagian bersama adalah bagian rumah susun yang dimiliki secara tidak terpisah 
untuk pemakaian

bersama dalam

kesatuan fungsi

dengan satuan-satuan

rumah susun.

4) satuan rumah susun

adalah unit rumah susun yang tujuan utamanya digunakan secara terpisah dengan fungsi utama sebagai tempat hunian dan mempunyai sarana penghubung ke jalan umum.

Pada poin 4 di atas, satuan rumah susun (sarusun) dapat diberikan hak baru yaitu Hak Milik atas Satuan Rumah Susun (HMSRS).

HMSRS merupakan hak baru yang sebelumnya tidak dikenal sebagai hak atas tanah dalam UUPA. Dalam perkembangannya

HMSRS telah mendapat pengaturan yang cukup jelas dan tegas dalam UU Rumah Susun, serta dikonsepkan sebagai salah satu hak dalam koridor sistem hukum tanah, terkait asas pemisahan horizontal dan asas perlekatan (assesi), sehingga HMSRS dapat dipersamakan dengan hak atas tanah. Oleh karena HMSRS dipersamakan sebagai hak atas tanah, maka peralihan HMSRS juga tunduk pada ketentuan peralihan hak atas tanah.

Jual beli (peralihan hak) menurut sistem hukum tanah nasional yang bersumber dari hukum adat, dikenal asas terang dan tunai, sehingga jual beli yang obyeknya HMSRS juga harus berdasarkan asas terang dan tunai. Terang artinya perbuatan hukum jual beli tersebut harus dibuat secara tertulis dihadapan pejabat yang ditunjuk/diangkat. Tunai artinya pada saat itu juga penjual menyerahkan barang dan pembeli membayar harga jual belinya. $^{4}$ Dengan demikian jual beli yang obyeknya berupa HMSRS juga harus mengikuti prosedur peralihan hak yang diatur dalam sistem hukum tanah, antara lain dilakukan di hadapan pejabat yang berwenang (PPAT) serta secara tunai. Dengan konsep di atas, maka developer hanya dapat menjual sarusun setelah obyeknya (sarusun) siap diserahterimakan dan menerima harga jual belinya secara tunai, sedangkan pembeli (users) siap untuk melakukan pembayaran secara tunai dan menerima sarusun yang dibelinya pada saat yang bersamaan. Transaksi jual belinya dilakukan di hadapan pejabat (PPAT) yang berwenang.

${ }^{4}$ Urip Santoso, Urip Santoso, Hukum Perumahan, (Jakarta: Kencana, 2014), hlm. 65 
b. Penjualan Secara Inden Melalui PPJB

Pengembang rumah susun, dimungkinkan untuk melakukan penjualan sarusun sebelum pembangunan rumah susun selesai melalui sistem PPJB, sebagaimana diatur dalam Pasal 43 UU Rumah Susun. Artinya developer di izinkan oleh aturan hukum untuk menjual sarusun walaupun obyeknya belum siap diserah-terimakan dan harga jual belinya belum dibayar lunas, melalui sistem perjanjian pendahuluan jual beli (PPJB). Dengan kata lain konsep jual beli menurut UUPA yang menganut asas terang dan tunai dapat disimpangi melalui penjualan secara inden dengan sistem PPJB yang merupakan perjanjian pendahuluan atau bantuan, sampai dengan jual beli HMSRS yang sesungguhnya terjadi. Melalui Pasal 43

UU Rumah Susun tersebut, negara bermaksud mengatur pembatasan kepada pengembang untuk menerapkan sistem PPJB kepada calon pembelinya (users) serta memberikan sanksi terhadap pelanggaran yang terjadi.

\section{Bentuk PPJB}

Menurut Pasal 43 ayat (1) UU Rumah Susun, yang menentukan: "Proses jual beli sarusun sebelum pembangunan rumah susun selesai dapat dilakukan melalui PPJB yang dibuat di hadapan notaris". Selanjutnya menurut Peraturan Pemerintah Nomor 12 Tahun 2021 tentang Perubahan Atas Peraturan Pemerintah Nomor 14 Tahun 2016 Tentang Penyelenggaraan Perumahan dan Kawasan Permukiman (selanjutnya disebut PP No. 12/2021) yang di dalam Pasal $22 \mathrm{~K}$ ayat (3) ditentukan: "PPJB ditandatangani oleh calon pembeli dan pelaku pembangunan yang dibuat di hadapan notaris". Dengan demikian berdasarkan ketentuan-ketentuan tersebut PPJB hanya dapat dibuat dalam bentuk akta yang dibuat di hadapan Notaris.

5. Kewajiban, Larangan dan Sanksi Pembuatan PPJB

a. Kewajiban

\begin{tabular}{lrrr}
\multicolumn{1}{c}{ Pasal } & 43 & ayat (2) \\
UURS & memuat \\
persyaratan & dan \\
kewajiban yang harus \\
dipenuhi pengembangan
\end{tabular} yang hendak melakukan penjualan sarusun yang belum selesai dibangun, yaitu::

1) status kepemilikan tanah; dibuktikan dengan sertipikat hak atas tanah atas nama pelaku pembangunan atau sertipikat hak atas tanah atas nama pemilik tanah yang dikerjasamakan atau dokumen hak atas tanah sesuai dengan 
ketentuan peraturan perundang-undangan di bidang pertanahan.

2) Persetujuan Bangunan

Gedung;

Dibuktikan dengan surat PBG

3) ketersediaan

prasarana, sarana, dan utilitas umum;

informasi yang jelas mengenai prasarana, sarana, dan utilitas umum yang dijanjikan oleh pengembang.

4) keterbangunan paling sedikit 20\% (dua puluh persen); keterbangunan paling sedikit $20 \%$ (dua puluh persen) adalah $20 \%$ (dua puluh persen) dari volume konstruksi bangunan rumah susun yang sedang dipasarkan.

b. Larangan

Menurut Pasal 98

UURS, Pengembang

dilarang membuat PPJB:

1) yang tidak sesuai dengan yang dipasarkan; atau

2) sebelum memenuhi persyaratan kepastian sebagaimana dimaksud dalam Pasal 43 ayat (2).

c. Sanksi

Menurut Pasal 110

UURS, Pengembang yang membuat PPJB:

1) yang tidak sesuai dengan yang dipasarkan; atau

2) sebelum memenuhi persyaratan kepastian sebagaimana dimaksud dalam Pasal 43 ayat (2);

sebagaimana dimaksud dalam Pasal 98, dipidana dengan pidana penjara paling lama 4 (empat) tahun atau denda paling banyak

Rp4.000.000.000,00 (empat miliar rupiah).

Ketentuan Pasal 110 UU Rumah Susun di atas, mengatur mengenai sanksi pidana terhadap pelanggaran ketentuan Pasal 98 jo. Pasal 43 ayat (2) UU Rumah Susun. Dengan telah diaturnya delik dan sanksi pidana, maka pelanggaran yang dilakukan pelaku usaha (developer) rumah susun terhadap ketentuan Pasal 43 ayat (2) UU Rumah Susun telah memenuhi kualifikasi sebagai tindak pidana.

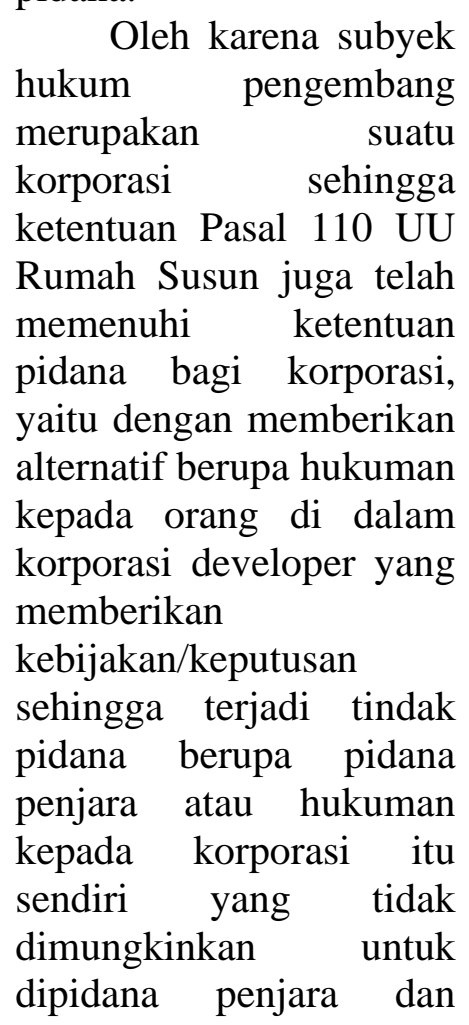




$$
\begin{array}{lr}
\text { hanya dimungkinkan } \\
\text { untuk membayar } \\
\text { sejumlah denda. }
\end{array}
$$

6. Kajian Putusan Pengadilan Terkait Pelanggaran Terhadap Kewajiban dan Larangan Pembuatan PPJB Penyimpangan

penyelenggaraan rumah susun masih banyak terjadi, antara lain pada kasus di Sleman, Yogyakarta dalam putusan Mahkamah Agung Nomor 549 K/Pid/2019.

Pada putusan tersebut, Terdakwa 1 (T1) dan Terdakwa 2 (T2), merupakan pendiri dan pemegang saham, serta selaku Komisaris dan Direktur dari sebuah perseroan terbatas (PT) yang bergerak di bidang pembangunan rumah susun. T1 dan T2 memasarkan dan menjual sarusun yang hendak dibangun dengan mengadakan pertemuan. Selanjutya terhadap penawaran yang dibuat $\mathrm{T} 1$ dan T2, kemudian saksi korban yang ikut hadir dalam pertemuan tersebut tertarik dengan penawaran yang diajukan sehingga membeli dan membayar sejumlah uang kepada T1 dan T2. Setelah 4 (empat) tahun berjalan ternyata pembangunan rumah susun belum juga dimulai, sehingga saksi korban melaporkan T1 dan T2 kepada Polisi, yang selanjutnya diproses hingga di sidang di Pengadilan Negari Sleman.

Jaksa Penuntut Umum (JPU) mendakwa T1 dan T2 melakukan tindak penipuan terkait penjualan sarusun tersebut menggunakan Pasal 378 KUHP. Terhadap dakwaan JPU tersebut, majelis hakim memberikan pertimbangan hukum, bahwa tindakan penjualan sarusun tersebut merupakan hukum perjanjian yang merupakan kewenangan hakim perdata, sehingga hakim menyatakan bahwa para terdakwa telah melakukan perbuatan sebagaimana yang didakwakan kepadanya sebagaimana dakwaan kesatu, akan tetapi perbuatan itu bukanlah merupakan suatu tindak pidana (Onslag Van Recht Vervolging).

Pada sidang tingkat kasasi, Judex Juris telah memberikan pertimbangan hukum (ratio decidendi) bahwa perbuatan hukum terdakwa merupakan pelanggaran terhadap ketentuan Pasal 43 ayat (2) juncto Pasal 98 UURS, namun sanksi pidana yang dipergunakan/dijatuhkan adalah Pasal 378 KUHP, padahal ketentuan Pasal 110 UURS, sebagai aturan hukum khusus (lex specialist) lebih tepat diterapkan, daripada aturan hukum hukum.

Sebagaimana diuraikan di atas, keberadaan Pasal 43 ayat (2), Pasal 98 dan Pasal 110 UURS merupakan derivasi dari Pasal 378 KUHP. Bahwa Pasal 110 memiliki alternatif mengenai subyek hukum yang bertanggung jawab, yaitu subyek hukum pidana penjara terhadap untuk orang 
(naturlijke persoon) atau sanksi pidana berupa denda untuk korporasi. Bahkan pada saat putusan kasasi diputus, para terdakwa (T1 dan T2) yang telah meninggal dunia atau almarhum, namun masih dijatuhi pidana penjara, merupakan sebuah ironi. Diterapkannya Pasal 378 KUHP daripada Pasal 110 UURS, oleh hakim menimbulkan ketidakpastian hukum terhadap pelanggaran Pasal 43 ayat (2) jo. Pasal 98 UU Rumah Susun. Menurut Philipus M. Hadjon yang mengutip pendapat Lon L. Fuller, menilai terjadi ketidakpastian hukum apabila terjadi salah satu prinsip dari 8 (delapan) prinsip, dalam hal ini prinsip kegagalan untuk mempublikasi atau memperkenalkan aturan hukum kepada masyarakat atau setidaknya kepada pihak yang berkepentingan yang diharapkan mempelajari aturan tersebut. ${ }^{5}$ Namun demikian berdasarkan Penjelasan Pasal 81 UU P3 yang menentukan: "Dengan diundangkannya Peraturan Perundang-undangan dalam lembaran resmi sebagaimana dimaksud dalam ketentuan ini, setiap orang dianggap telah mengetahuinya".

Hal tersebut merupakan pemberlakuan teori fiksi hukum, yang beranggapan ketika suatu peraturan perundang-undangan telah diundangkan, maka pada saat

5 Philipus M.Hadjon, Perlindungan Hukum Bagi Rakyat Indonesia, (Surabaya: Bina Ilmu, Surabaya, 1987), hlm. 90. itu semua orang dianggap tahu (presumption iure de iure) dan ketidaktahuan seseorang atas hukum atau peraturan perundangundangan yang berlaku tidak membebaskan seseorang itu dari tuntutan hukum (igronantia iuris neminem excusat).

Tanggung Jawab Pidana Notaris Terhadap Terjadinya Tindak Pidana Di Dalam Akta Notaris

1. Prinsip Kehati-hatian Notaris

Notaris dalam menjalankan jabatannya (membuat akta otentik) wajib menjaga prinsip kehati-hatian yang erat kaitannya dengan ketelitian, kecermatan dan kesaksamaan yang memiliki arti yang sama, agar akta yang dibuatnya tidak menimbulkan permasalahan hukum di kemudian hari. Sehingga tujuan masyarakat datang dan meminta bantuan jasa notaris, agar perbuatan hukum, perjanjian atau penetapan yang hendak mereka dilakukan dimuat ke dalam akta notaris menjadi alat bukti yang kuat dan sempurna menjadi tercapai.

Kesaksamaan menjadi hal penting dilakukan oleh notaris dalam menjalankan jabatannya, karena masyarakat yang datang dan meminta bantuan jasa notaris sebagai suatu profesi bidang hukum yang memiliki keahlian khusus dan tanggung jawab. Menurut Liliana Tedjosaputro dalam 
Ghansham Anand, ${ }^{6}$ profesi notaris merupakan jabatan kepercayaan yang bertanggung jawab secara hukum, moral dan etika kepada negara/pemerintah dan masyarakat yang menjadi pihak-pihak dalam akta. Walaupun pada

penjelasan umum UUJN disebutkan akta notaris pada hakikatnya memuat kebenaran formal sesuai permintaan/kehendak para pihak yang disampaikan/diberitahukan kepada notaris, namun notaris mempunyai kewajiban untuk menjelaskan bahwa hal-hal yang dimuat dalam akta notaris telah dimengerti dan sesuai kehendak para pihak sendiri. Kewajiban notaris untuk menjelaskan tersebut menuntut seorang notaris mengerti dan memahami karakteristik perbuatan hukum yang dimuat ke dalam akta, sehingga perbuatan hukum yang dimuat/dinyatakan ke dalam akta tidak melanggar hal-hal yang dilarang oleh aturan hukum.

2. Kajian Putusan Pengadilan Yang Memberikan Sanksi Pidana Kepada Notaris Terkait Pembuatan Akta

Penelitian ini juga mengkaji perkara pidana yang melibatkan notaris terkait pembuatan akta, yang di dalamnya memuat suatu tindak pidana. Putusan yang akan dikaji merupakan

6 Ghansham Anand, Karakteristik Jabatan Notaris Di Indonesia, (Jakarta: Kencana, 2018), hlm. 96. penerapan metode argumentum per anoalgium (analogi), yaitu terhadap peristiwa serupa atau mirip, yang dapat dilihat pada Putusan Pengadilan Tindak Pidana Korupsi pada Pengadilan Negeri Surabaya Nomor 62/Pid.SusTPK/2017/PN.Sby jo. Putusan Pengadilan Tindak Pidana pada Pengadilan Tinggi Jawa Timur Nomor 86/Pid.SusTPK/2017/PT.SBY.

Berdasarkan putusan pengadilan yang memberikan sanksi pidana kepada notaris terkait pembuatan akta di atas, penulis memberikan analisa sebagai berikut:

a. Notaris dalam menjalankan jabatannya disamping harus berpedoman pada UUJN juga harus patuh pada peraturan perundangundangan lainnya sebagaimana sumpah/janji yang diucapkan notaris.

b. Walaupun dalam penjelasan umum UUJN disebutkan pada dasarnya notaris hanya bertanggung jawab terhadap kebenaran formil yang diberitahukan para pihak kepada notaris, dan tidak bertanggung jawab terhadap isi/materiil yang dimuat dalam badan akta. Akan tetapi berdasarkan Pasal 4 UUJN terkait sumpah/janji untuk patuh pada peraturan perundang-undangan, demikian pula menurut 
Pasal 16 ayat (1) huruf a UUJN terkait prinsip kehati-hatian jo. Huruf e, terkait kewajiban menolak membuat akta apabila perbuatan hukum yang dimuat dalam akta terdapat hal yang dilarang oleh peraturan perundangundangan, maka notaris sebagai pejabat umum yang diberikan wewenang oleh negara, seharusnya menjadi filter atau penyaring, terhadap pelanggaran yang hendak dilakukan masyarakat.

c. Hakim berwenang melakukan penemuan hukum yang salah satunya melalui metode konstruksi hukum yang dibutuhkan dalam menghadapi kekosongan hukum. Menurut Philipus M. Hadjon, model kontruksi hukum terdiri dari analogi dan gandengannya

(spiegelbeeld) acontrario, dan bentuk ketiga, yang oleh $P$. Scholten disebut sebagai penghalusan hukum (rechtsverfijning) yang dalam bahasa Indonesia oleh disebut penyempitan hukum. $^{7}$

d. Dalam pertimbangan hukum (ratio decidendi), hakim melakukan penemuan hukum melakui konstruksi hukum menggunakan

${ }^{7}$ Philipus M. Hadjon dan Tatiek Sri Djatmiati, Pengantar Hukum Adminstrasi Negara, (Yoyakarta: Gajah Mada University Pers, 2008), hlm. 26 metode Argumentum a Contrario.Metode ini menggunakan penalaran bahwa jika undangundang menetapkan halhal tertentu untuk peristiwa tertentu, berarti peraturan itu terbatas pada peristiwa tertentu dan bagi peristiwa di luarnya berlaku kebalikannya. $^{8}$

Berdasarkan asas hukum pidana bahwa tiada pidana tanpa kesalahan (geen straf zonder schuld), maka dengan metode Argumentum a Contrario, dapat dimaknai bahwa apabila seseorang melakukan kesalahan, maka orang tersebut dapat dipidana, sehingga majelis hakim berpendapat seorang notaris pun dapat dipidana apabila dalam menjalankan jabatannya dia melakukan kesalahan (schuld) yang dapat dipertanggungjawabkan dalam hukum pidana.

e. Berdasarkan bukti-bukti dan fakta persidangan, berupa keterangan saksi dan rangkaian perbuatan yang dilakukan notaris, dapat dibuktikan bahwa notaris mengetahui adanya pelanggaran hukum berupa pengalihan TKD yang secara hukum tidak dapat dialihkan, bahkan notaris membuatkan alat bukti pengalihannya. Dengan 
demikian terbukti bahwa

notaris melakukan

kesalahan dalam

menjalankan jabatannya.

f. Bantahan terdakwa yang menyatakan tidak mengetahui adanya TKD sehinga tidak mengetahui adanya pelanggaran hukum, sebagai unsur pemaaf/penghapus

kesalahan terbantahkan oleh keterangan saksi dan fakta persidangan.

g. Berdasarkan fakta hukum dan keterangan saksi, menunjukkan notaris melakukan kesalahan yang disengaja membuat akta, yang mana terbukti sehingga kesengajaan untuk melakukan kesalahan tersebut dikategorikan sebagai penyalahgunaan wewenang.

\section{Status Kepemilikan Tanah Rumah Susun Perspektif Hukum Ekonomi Syariah}

Di dalam hukum Islam, status kepemilikan tanah pada rumah susun termasuk dalam kategori hak alirtifaq. Di beberapa literatur fiqh muamalat haq Al-irtifaq di sebut juga dengan milk al-manfaah al-'aini. Secara etimologi irtifaq berarti pemanfaatan terhadap sesuatu. Sedangkan terminologi dari hak irtifaq adalah "Hak pemanfaatan benda tidak bergerak, baik benda itu milik pribadi atau milik umum."

Adapun di antara sebab-sebab munculnya haq Al-irtifaq adalah: (1) Adanya ikatan kebersamaan (alSyirkah Ammah), (2) Adanya kesepakatan pihak yang berakad dan (3) Adanya kesepakatan ketetanggaan ( kesepakatan Jaaru/Jiwar).

Adapun macam-macam haq irtifaq adalah sebagai berikut :

1) Haq as-Syurb adalah hak manusia atau hewan terhadap air untuk memanfaatkannya. Dalam hak, ini ulama mambagai air kepada 4 macam : a) air yang ditampung dalmam tempat khusus oleh pemiliknya, b) air sumur, c) air sungai khusus yang melewati lahan pribadi tertentu atau pengairan yang dibuat orang/kelompok tertentu, dan e) air sungai besar (umum). Dasar hukum hak ini adalah hadits Rasulullah yang diriwayatkan oleh Ahmad ibn Hanbal, atTirmidzi, an-Nasa'i, Ibnu Majah dan Ibnu Hibban, yang berbunyi : "Manusia itu berserikat dalam tiga hal yaitu air, rumput, dan api." \{HR. Ahmad ibn Hanbal \}

2) Haq al-Majra adalah hak pemilik lahan yang jauh dari aliran air untuk irigasi dalam rangka mengairi lahannya, baik melalui lahan orang lain ataupun tidak. Dasar hokum dari hak ini adalah kasus antara dua orang sahabat yang bertengkar dalam persoalan air, pemilik lahan yang dekat dengan sumber air tidak mau mengalirkan air atau tidak mau lahannya dijadikan aliran air ke lahan orang yang jauh dari sumber air. Ketika Umar bin Khattab berupaya mendamaikan keduanya, pemilik lahn yang dekat dengan sumber air tetap bersih keras dengan pendiriannya. Akhirnya Umar bin Khattab berkata :Đemi Allah saya akan mengalirkan air itu,sekalipun melalui perut engkau", kisah ini diriwayatkan imam malik dalam 
kitabnya, al-Mumatta' Juz II.

3) Haq al-Masil adalah hak seseorang untuk menyalurkan kotoran, baik manusia atau pun rumah tangga, ke penampungan atau saluran umum dengan mempergunakan selang yang melalui jalan raya, lahan, rumah dan perusahaan milik orang lain. Pemanfaatan hak ini tidak boleh mengganggu kemaslahatan orang lain. Maka dari itu, pemilik hak berkewajiban memelihara atau mengamati secara intensif alat yang dipergunakan untuk mengalirkan limbah tersebut.

4) Haq al-Murur / ath-Thariq adalah hak seseorang untuk sampai kerumah atau lahannya dengan melalui lahan orang lain, baik milik umum ataupun pribadi. Misalnya, irham berjalan menuju rumahnya melawati depan rumah hamid. Ulama fiqh membagi permasalahan dalam hak ini ke dalam 2 macam : a) apabila yang dilewati jalan raya, maka semua orang dapat memanfaatkan jalan tersebut (melewati, parkir, berjualan ) asalkan tidak menimbulkan mudharat pada orang lain, b) apabila jalan yang dilewati adalah jalan khusus, boleh dipergunakan ketika jalan raya sedang padat. Namun, tentunya pemilik hak harus menjaga agar jalan tersebut tidak rusak sehingga dapat menimbulkan kemudharatan bagi orang lain.

5) Haq at-Ta'ali adalah hak seseorang untuk tinggal di tingkat

\section{KESIMPULAN}

Berdasarkan pembahasan dan hasil penelitian, maka kesimpulan yang dapat diambil dari penelitian ini atas pada perumahan bertingkat (aparteman, hotel) dan menjadikan loteng rumah orang di tingkat bawah sebagai lantainya.

6) Haq al-Jiwar adalah hak seseorang untuk tinggak bersebelahan dengan tetangganya disebabkan saling bertemunya batas milik masing-masing. Para ulama sepakat dalam keadaan seperti ini, masing-masing pemilik boleh memeanfaatkan milik tetangganya, selama tidak membawa mudharat kepada tetangganya itu. Misalnya, dinding rumah menyatu, maka masing-masing pihak boleh mempergunakan dinding tersebut untuk menggantung lukisan atau perabotan lainnya.

Apabila dilihat dari keenam macam hal al-irtifaq di atas, maka kepemilikan tanah pada rumah susun termasuk haq al-jiwar dimana setiap penghuni rumah susun tersebut berhak atas tanah dimana rumah yang mereka tinggali tersebut dibangun. Karena itu pemanfaatan tanah hendaknya atas kesepakatan bersama-sama selmua penghuni atau pemilik rumah susun tersebut. Apabila terjadi pelanggaran pemanfaatan tanah bersama tersebut, dalam hukum ekonomi syariah tidak secara jelas menyebutkan sanksinya, tetapi menurut penulis sanksi dalam pelanggaran penguunaan tanah seperti itu lebih berkaitan dengan hukuman tahzir (perintahan) saja, dan tidak sampai pada ranah pidana Islam (hudud).

adalah sebagai berikut: Pertama, Undang-Undang Nomor 20 Tahun 2011 tentang Rumah Susun merupakan pedoman bagi 
pengemban hukum (stakeholders), pelaku usaha dan masyarakat yang di dalamnya telah diatur hal-hal yang berkaitan dengan penyelenggaraan rumah susun di Indonesia, termasuk adanya sanksi bagi yang melakukan pelanggaraan terhadap ketentuan yang diatur di dalamnya. Dalam terjadi terjadi pelanggaran hukum terkait penyelenggaraan rumah susun, maka sanksi yang diatur didalamnya yang dipergunakan sebagai dasar penegakan hukum. Kedua, kepemilikan tanah pada rumah susun termasuk haq al-jiwar yang termasuh dalam ranah hak alirtifaq, dimana setiap penghuni rumah susun tersebut berhak atas tanah dimana rumah yang mereka tinggali tersebut dibangun. Karena itu pemanfaatan tanah hendaknya atas kesepakatan bersama-sama semua penghuni atau pemilik rumah susun tersebut. Apabila terjadi pelanggaran pemanfaatan tanah bersama tersebut, dalam hukum ekonomi syariah tidak secara jelas menyebutkan sanksinya, tetapi menurut penulis sanksi dalam pelanggaran penguunaan tanah seperti itu lebih berkaitan dengan hukuman tahzir (perintahan) saja, dan tidak sampai pada ranah pidana Islam (hudud), karena bukan termsuk bagian dari masalah kriminal.

\section{Referensi}

[1] Siswono Judohusodo, Rumah Untuk Seluruh Rakyat, Jakarta: Inkoppol Unit Percetakan Bharakerta, 1991.

[2] Peter Mahmud Marzuki, Penelitian Hukum, Cetakan 14, Jakarta: Kencana Prenada Media Group, 2019.

[3] Ibid, 55-56.

[4] Pasal 1 ayat (1) Peraturan Menteri Agraria Dan Tata Ruang/Kepala Badan Pertanahan Nasional Republik Indonesia Nomor 17 Tahun 2019 Tentang Izin Lokasi.

[5] Urip Santoso, Urip Santoso, Hukum Perumahan, Jakarta: Kencana, 2014.

[6] Philipus M.Hadjon, Perlindungan Hukum Bagi Rakyat Indonesia, (Surabaya: Bina Ilmu, Surabaya, 1987), hlm. 90.

[7] Ghansham Anand, Karakteristik Jabatan Notaris Di Indonesia, Jakarta: Kencana, 2018.

[8] Philipus M. Hadjon dan Tatiek Sri Djatmiati, Pengantar Hukum Adminstrasi Negara, Yoyakarta: Gajah Mada University Pers, 2008. 